A Journal of Culture, English Language Teaching \& Literature

ISSN 1412-3320 (Print), ISSN 2502-4914(Online)

Vol. 16 No. 1; July 2016

Copyright (C) Soegijapranata Catholic University, Indonesia

CODING LOGICAL MECHANISM AND STEREOTYPING IN GENDER CYBER HUMORS

Truly Almendo Pasaribu \& A. Effendi Kadarisman

Sanata Dharma Univesity \& State University of Malang, Indonesia

Tel +62 81903751177

$+6281331452486$

Email: tr.almendo@gmail.com

effendi.kadarisman@gmail.com

Received: 25-11-2015

Accepted: 14-07-2016

Published: 31-07-2016 


\title{
CODING LOGICAL MECHANISM AND STEREOTYPING IN GENDER CYBER HUMORS
}

\author{
Truly Almendo Pasaribu \& A. Effendi Kadarisman \\ tr.almendo@gmail.com; effendi.kadarisman@gmail.com \\ Sanata Dharma University \& State University of Malang, \\ Indonesia
}

\begin{abstract}
This research aims to find out types of logical mechanism and ways of stereotyping in gender cyber humors. For this purpose, both researchers have collected 50 gender cyber humors and analyzed them, primarily using Attardo's (2011) General Theory of Verbal Humor (GTVH) to explicate the logical mechanism or the inner structure of the humors. The findings show that there are 10 (ten) types of logical mechanism: two most dominant types (i.e., put-down humor and false analogy), four less dominant (i.e., lexical repetition, absurd neologism, absurd interpretation, and fallacious reasoning), and four least dominant (i.e., twisting figures of speech, prepositions, homonyms, and idioms). Interestingly, there is some correlational tendency that the more dominant the types, the more complex their linguistic structures. As for gender stereotyping, both men and women are taken as targets of humor. Men are ridiculed for being stupid, ugly, stubborn, immature, and addicted to drinking and gambling, whereas women are ridiculed for being bothersome, economically dependent, absorbed in home-making, and jealous. Strangely enough, both men and women are made fun of for being insignificant and excessive money spenders. Most stereotypes are in accord with traditional roles of men and women; only the last two sound non-traditional, probably owing to the success of recent feminist movements.
\end{abstract}

Key words: gender cyber humors, logical mechanism, gender stereotyping

Abstrak: Penelitian ini bertujuan menguak tipe-tipe mekanisme humor and tata-kerja stereotip dalam humor berbalut-gender. Untuk tujuan ini, 
Stereotyping in Gender Cyber Humors

kedua peneliti mengumpulkan 50 humor berbalut-gender dari situs-web and menganalisis seluruh humor tersebut menggunakan Toeri Umum Humor Verbal Attardo (2011), terutama untuk mengungkap mekanisme atau struktur hakiki dari humor. Temuan penelitian menunjukkan bahwa mekanisme humor ada 10 (sepuluh) tipe: dua tipe paling dominan (yaitu humor-mengejek dan humor dengan analogi palsu), empat tipe kurang dominan (yaitu pengulangan leksikal, neologisme aneh, penafsiran aneh, dan penalaran yang menipu), dan empat tipe tak-dominan (yaitu memelintir gaya bahasa, preposisi, homonym, dan idiom). Yang menarik, nampaknya ada kecenderungan korelasional: semakin dominan tipe humor, semakin kompleks struktur linguistiknya. Sedangkan mengenai tata-kerja stereoptip, baik laki-laki maupun perempuan keduanya dijadikan target olok-olok humor. Laki-laki diejek karena bodoh, burukrupa, keras-kepala, kekanak-kanakan, dan menjadi pecandu minuman dan judi; sementara perempuan diejek karena cerewet, bergantung ekonominya, cuma sibuk dengan urusan rumah tangga, dan pencemburu. Anehnya, baik laki-laki maupun perempuan keduanya diledek karena berkepribadian dangkal dan berwatak boros. Sebagian besar stereotip sesuai dengan peran tradisional laki-laki dan perempuan; hanya sifat dangkal dan boros yang bernuansa non-tradisional, kemungkinan besar sebagai akibat keberhasilan gerakan feminisme pada saat ini.

Kata kunci: humor berbalut-gender, mekanisme humor, stereoptip berbasis-gender

\section{INTRODUCTION}

Almost everyone agrees that humors are creatively produced and intended to be humorous. It is not only humorous, but also healthy. The health benefits of humor are well documented by the scientific and medical community (Bennett, 2006). Because of their virtues, we can find them almost everywhere in our daily lives, such as in media and social interactions. Ironically, not every humor fascinates people; there are some humors which are considered to be more negative phenomena. In this case, it refers to those with crude ideas behind them and they should not be taken for granted in the academic world, e.g. ethnic jokes, political humors, gender humors, and many others.

In the academic world, Paramitasari (2007) and Azis (2008) examined the ambiguities found in humors. The two researchers mainly focused on the incongruity aspect of the humor in the form of ambiguities which are responsible for creating comical effects. The incongruity theorists suggested 
that amusement or humor is the result of the unexpected. Koestler (1964) claimed that humor shows how creative the human minds are through the wittiness scattered in humors. The incongruities through language, gestures and pictures are indeed examples of the creative cognitive process, which is also claimed by other prominent thinkers of incongruity theories of humor such as Schopenhauer and Kant (Monro, 1988). Incongruity theories gave rise to a formal theory of humor called the General Verbal Theory of Humor (GTVH), a term introduced by Attardo (2001). Like Chomskyan generative grammar (see Chomsky 1957, 1965), this theory also consists of layers that explain the content of humor. The layers are known as Knowledge Resources (KR); from the most abstract to the most concrete are Script Opposition, Logical Mechanism, Situation, Target, Narrative Strategy, and Language. It is interesting to note that the targets in humors are the butts of the humors based on person or group stereotypes (Attardo and Raskin, 1991). In today's usage, stereotypes most often denote unfavorable or hostile pictures toward other people based on their membership in another social or ethnic group.

Having a different perspective from the two researchers above, we argue that there are larger numbers of humors that do not violate linguistic features alone, such as ethnic humors and gender humors. Plato and Aristotle were originators of the theories of superiority many centuries ago. These theories, developed by Hobbes and used in sociology by Bergson, predominated for over two thousand years and explained laughter as the result of feelings of superiority over others or over our own former position (Monro, 1988). These scholars claim that the sense of humor is positively related to general traits of aggression, hostility, or dominance. These theories accentuate the negative attitude of the producer and/or user of humor towards its target and the often alleged aggressive character of laughter. These superiority and inferiority elements touch upon the social aspect of the humor. Another interesting relationship between humor and society has been observed by Laineste (2008), a sociologist, who stated that humor tells a lot about its surrounding because humor gives us the knowledge about standardized images of the society.

Gender humors are humors involving gender matters that trigger people's laughter. Gender humors constitute one thought-provoking topic to investigate because it shows how creative human minds are in manipulating language, and at the same time it also tells a lot about the social aspect of the humor through stereotypical image. The link between humor and social domain was highlighted by Schwars (2010) who argued that humor increased when the target of the joke was someone or a group of persons we do not 
like; in this case, humor served as a means of expressing social superiority. Moreover, humor can be manipulated as a tool to reinforce or even transform stereotypical images. Moranjak-Bamburac (2006, p. 17) stated that "Stereotypes are simplified and generalized mental images or views which distort our concepts of reality." She also added that due to humans' cognitive capacity, stereotypes were resistant to change. Gender stereotypes are images, usually negative ones, about social roles, identities, and representations of male and female. Another very thought-provoking study of the gender traditional role is done by Chavetz (1978). In her pioneering work in this area, she summarized masculine and feminine gender role stereotypes for seven human characteristics, based on her 1971 study of students' attitudes. She found that her subjects of study described the concept of "masculine" with such adjectives as athletic, breadwinner, sexually aggressive, unemotional, logical, dominating, etc. "Feminine" traits were described with such adjectives as weak, domestic, sexually passive, emotional, intuitive, dependent, etc.. Londo (2006) also investigated that women's magazines offered stereotypes of family and motherhood, which led women to believe that self-actualization was not possible without a family or children. Through binary opposition, both types of gender-specific indexing serve as structures of power-relation (Derrida, 1978). It is obvious, then, that in the concept of masculinity and femininity, the former one is more dominant in the binary opposition. Worse, stereotypes consciously or unconsciously dictate how and by whom and when it is socially acceptable to display an emotion; so they influence how an individual performs (Spencer, Steele, and Quinn, 1999). On the basis of the research background outlined above, the aims of the present research are twofold: first, to find out types of logical mechanism, and secondly, to figure out ways of stereotyping in gender cyber humors.

\section{RESEARCH METHOD}

This study investigates verbal data taken from a humor website, Aha!jokes.com. This site has become recognized as a leader of jokes and humor on the World Wide Web by offering fresh jokes, text files, audio files, video clips, pictures, cartoons, and animations. Google gives this site a high rate when the researchers surfed for "gender jokes", indicating that this site is often visited or considered as one of the favorite humor websites. Aha!jokes.com was first on-line in August 2001 and has been rapidly growing by updating its jokes ever since. The present research, using a descriptive qualitative design in the sense of Patton (1990), Latief (1999), and Ary et. al. 
(2002), collected the data using a purposive sampling technique; for the researchers intentionally selected 50 gender-related humors from the above website. We analyzed the humors to uncover their logical mechanism and linguistic manipulation in them using Attardo's (2001) General Theory of Verbal Humor (GTVH). Moreover, we also dissected the humors to expose how gender stereotyping operates in them, and eventually to assess how gender opposition portrays men and women in their social and familial roles, as seen from traditional and non-traditional perspectives.

\section{FINDINGS AND DISCUSSION}

This section presents research findings resulting from data analysis under two sub-headings: (1) logical mechanism and targets of humors, and (2) stereotyping in gender humors. The first sub-section discusses types of logical mechanism of gender humors, focusing on three aspects: identifying the male or female targets, specifying the formal rules governing the mechanism, and explicating the linguistic features under manipulation. The second sub-section discusses gender stereotypes in gender humors, pointing out which stereotypes belong to which gender and why, and explaining the shifting tendency from the traditional male dominance to the non-traditional male-and-female equality.

\section{A. Logical Mechanism and Targets of Humors}

In analyzing the data, the researchers classify the selected 50 gender humors in terms of their logical mechanism, and relate each type of logical mechanism to the target of humor: man and/or woman. Logical mechanism, according to Attardo and Raskin (1991), addresses how the various elements such as linguistic devices in the humorous exchange are conjoined to feed the need of laughter. As shown in Table 1, 10 types of logical mechanism are presented in sequence, from the humor that involve exploiting smaller linguistic units to more complex ones. Thus, linguistically speaking, type (1), Twisting Prepositions, is very simple; type (5), Absurd Neologism, is relatively complex; and type (10), Put-down Humor, is extremely complex. In terms of frequency, at the top are Put-down Humor (28\%) and False Analogy (24\%); in the middle are Word Repetition (10\%), Absurd Neologism, Absurd Interpretation, and Fallacious Reasoning, (10\%) each; and at the bottom are Twisting Prepositions (4\%), Twisting Homonymy, and Twisting Figurative Language, (2\%) each. Notice that linguistic complexity does not prevent writing sophisticated humor. In fact, the tendency goes in the reverse order: 
Pasaribu, Truly A. \& Kadarisman, A. E., Coding Logical Mechanism and

Stereotyping in Gender Cyber Humors

the more complex linguistically, the more frequently the humors occur. This suggests that gender humor writers seem to prefer writing humors with greater linguistic complexity, and hence logically more challenging and comically more appealing.

Table 1:

Logical Mechanism and Targets of Humors

\begin{tabular}{|c|c|c|c|c|c|c|c|}
\hline \multirow{2}{*}{ No. } & \multirow{2}{*}{ Logical Mechanism } & \multirow{2}{*}{$\sum$} & \multirow{2}{*}{$\%$} & \multicolumn{2}{|c|}{ Man } & \multicolumn{2}{|c|}{ Woman } \\
\hline & & & & $\sum$ & $\%$ & $\sum$ & $\%$ \\
\hline 1 & Twisting Prepositions & 2 & 4 & 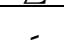 & - & 2 & 4 \\
\hline 2 & Twisting Homonymy & 1 & 2 & - & - & 1 & 2 \\
\hline 3 & $\begin{array}{l}\text { Twisting Idiomatic } \\
\text { Expressions }\end{array}$ & 1 & 2 & - & - & 1 & 2 \\
\hline 4 & $\begin{array}{l}\text { Twisting Figurative } \\
\text { Language }\end{array}$ & 3 & 6 & 3 & 6 & - & \\
\hline 5 & Absurd Neologism & 4 & 8 & 3 & 6 & 1 & 2 \\
\hline 6 & Absurd Interpretation & 4 & 8 & - & - & 4 & 8 \\
\hline 7 & False Analogy & 12 & 24 & 5 & 10 & 7 & 14 \\
\hline 8 & Fallacious Reasoning & 4 & 8 & 3 & 6 & 1 & 2 \\
\hline 9 & Word Repetition & -5 & 10 & 2 & 4 & 3 & 6 \\
\hline 10 & Insult or Put-down Humor & 14 & 28 & 8 & 16 & 6 & 12 \\
\hline & 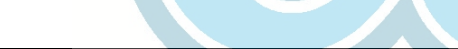 & & & & & & \\
\hline & TOTAL & 50 & 100 & 24 & 48 & 26 & 52 \\
\hline
\end{tabular}

Legends (for mathematical symbols used in this sention):

$=$ is $/$ equals

$\wedge=$ is not synonymous with

$\rightarrow{ }^{\prime} . . \wedge \ldots=$ is not $\ldots$ in the puch line

$\sim$ does not have

As for the targets of humor, both man and woman share almost the same destiny (48\%:52\%). Each type of gender equally serves as a butt or victim of the jokes. This may lead to a tentative conclusion that gender equality now prevails nicely in the English-speaking world; and this will be discussed more fully in the second sub-section.

After identifying the general characteristics, below we are presenting detailed analyses, giving elaboration to each type of logical mechanism of gender humors (see Table 1), starting with the linguistically simple and moving down to reach the linguistically complex. For each type of logical 
mechanism, one or two illustrative examples are provided and analyzed thoroughly to reveal the incongruities, by exposing the semantic features belonging to twisted linguistic expressions, whenever necessary, and by making use of Attardo's (2001) General Theory of Verbal Humor (GTVH) to uncover the witty play of logic behind the narrative strategy.

\section{Twisting Prepositions}

Some linguistic devices can be deliberately exploited to create a thrill of laughter; one of them is preposition. Interestingly, most prepositions, like on, in, at, contain more than one entry in the dictionary. Consequently, it is possible for a preposition to have more than one meaning if the context or the script opens a way for ambiguity. Take a look at example 1 :

(1) One golfer tells another: "Hey, guess what! I got a set of golf clubs for my wife!" The other replies: "GREAT trade!" (Datum 1)

Based on GTVH, the structure of humor (1) can be elaborated as in Table 2.

Table 2:

Logical Mechanism of Humor (1)

\begin{tabular}{|l|l|}
\hline \multicolumn{1}{|c|}{ Parameters } & \multicolumn{1}{c|}{ Structure of Humor } \\
\hline Script Opposition & Given/exchanged \\
\hline Target & Woman \\
\hline Narrative Strategy & Short Narrative \\
\hline Language & $\begin{array}{l}\text { Set-up: } \\
\text { One golfer tells another, "Hey, guess what! I got a } \\
\text { set of gold clubs for my wife!" } \\
\text { Punch Line: } \\
\text { The other replies, "Great trade!" }\end{array}$ \\
\hline
\end{tabular}

In this case, the expression "I got a set of golf clubs for my wife!" is constructed to give this image:

a. I got something.

b. That something is a set of golf clubs for (given to) my wife.

As a result, the set-up is likely to be interpreted that a set of golf clubs is a gift presented to the wife by the husband. On the other hand, it is unlikely that the reader chooses another way to interpret the constructed set-up. 
The rest of the humor is purely a linguistic choice that creates a semantic obstacle for the reader. The given punch line "Great trade!", which is also compatible with the text, succeeds in twisting the whole expected meaning of the set-up. This reply becomes compatible after the reader realizes that the preposition "for" makes a way for ambiguity. Having come across with the twisted punch line, the reader has to look back and reconstruct a possible relation between the surface and deep levels (script opposition) of the sentence. Only after arriving at the punch line is the reader aware that actually there are two thinkable alternative meanings given in this humor. To make it clearer, below is the formulation of the humor. If $\mathrm{X}$ is the ambiguous word, $\mathrm{M} 1$ the expected meaning, and M2 the second interpretation, then the humor can be interpreted as:

$\mathrm{X}$ for

$\mathrm{Ml}$ intended to be given/received by the wife

M2 in exchange for the wife

Set-up:

$\mathrm{X}=\mathrm{M} 1, \mathrm{X}=\mathrm{M} 2 \mathrm{Ml} \wedge \mathrm{M} 2^{1}$

(Verbal reading of each mathematical notation is given at the end of this article.)

The set-up leads the reader to expect:

$\mathrm{X}=\mathrm{M} 1$

However, the spatial incongruity between the different meanings of the preposition "for" is finally established by the use of the word "trade". So, the punch line can be written as:

$$
\mathrm{X}=\mathrm{M} 2-» \mathrm{X}^{\wedge} \mathrm{M} 1^{2}
$$

Hence, having met this semantic obstacle inside the script opposition (the different possible meanings of the preposition "for"), the reader is forced to twist the image into something like this:

a. I got something.

b. That something is a set of golf (in exchange) for my wife. 
Semantically analyzed, wife [+ANIMATE, +HUMAN, +PARTNER, -THING] cannot be bartered for golf clubs [-ANIMATE, -HUMAN, -PARTNER, + THING]. Some people find the remarks "great" funnier because it pictures how very lucky the husband is by having successfully traded his wife for a set of golf clubs. It should be kept in mind that this element of superiority or depreciating "the other" also accounts for the humorous effect. In fact, it plays an important role in the humor. If "the wife" is changed with "the husband", it possibly creates different effects of laughter because stereotypically a "woman" is not into sports, especially golf. Furthermore, the image of a woman as "the insignificant one", or "the other" is clearly apparent since a set of golf clubs-an object-is considered to be more valuable than the wife. Possibly, the word "great" which is deliberately put in the humor arouses more laughter. Thus, if men or even women are laughing at this humor, they laugh not only at the subtle incongruity but also, consciously or not, at the insignificant images assigned to a wife.

\section{Twisting Partial Homonymy}

Pun is one phenomenon that shows how closely related humor and language are. There are some types of puns that are found in great literature, such as homonyms, homophones, and homographs (Kadarisman, 2002). This humor below manipulates one type of pun, homonymy, to stimulate laughter. Homonymy is a case where there are words that are identical in sound and spelling (Liang, 2007). In general, homonym is a word that is spelled and pronounced in the same way has different meanings. Although they have similar sounds and spellings, homonyms in everyday usage rarely create confusion because they are used in a certain context. However, due to their unique features, they can be exploited as an indicator of humor, like humor 2:

(2) Woman's Instruction: If he asks what sort of books you're interested in, tell him checkbooks. (Datum 3)

The punch line creates a need to spatially bring together the word "book" with "checkbook". The spatial incongruity between book and checkbook is linked by the same spelling of the second syllable in checkbook and book and the same sound they have, /buk/. Having the same spelling and sound, the different words are treated as a similar word in the surface of the humor. Therefore, the punch line is twisted by telling that checkbook is a kind of book. 
Furthermore, the social logic behind the humor also contributes to its creation. It is clearly seen that the humor above pokes fun at the woman's expense. The humor gives the image that shows how women instruct other women to be materialistic and dependent on men in terms of economic support. It should be noticed how women are constructed to be dependent on men. This shows that male dominance is still maintained in earnings. As suggested by Schwars (2010), humor served as an instrument of expressing power in particular social domain. In other words, this humor, to some extent, preserves the traditional social role of male as the money-maker and female as the money-spender.

\section{Twisting Idiomatic Expressions}

Advanced English Idioms defines idiom as a constructed group of words that has a special meaning that is different from the ordinary meaning of each individual word (Lim, 2004). These multi-constructed words are combined into a semantic unit whose meaning cannot be deduced from the meanings of its constituents. In other words, if the meanings of the words constructing an idiom are separated, it will destroy the frozen meaning of the idiom. Because an idiom has a non-productive syntactic structure, it is impossible to add, delete or modify the arrangement of words in fixed idioms. Nevertheless, frozen idioms, when used in the production of humor, are deliberately treated in a different manner. An example is the following humor:

(3) What are two reasons why women don't mind their own business?

1) No mind.

2) No business. (Datum 4)

Fixed expressions in idioms have their continuous echoing meaning throughout ages. However, in the punch line, the idiomatic expression is destined to unveil their initial figurative freshness in order to arouse the humorous effect. The humor exploits the idiomatic expression by separating it into each separate word. The disconnection between the meaning of the words in the idiomatic arrangement results in absurdity and incongruity, which produce surprise. The word "mind" in the idiomatic expression functions as a verb which is equivalent to "to attend", whereas the word "business" functions as a metaphor to indicate "affair". Indeed, defining "mind" [THINKING CAPACITY] and "business" [WORK] individually is not expected, and triggers laughter. 
Exploiting linguistic devices may contribute additional thrill to the humorous effect. And yet, the humor also depends on the social implication of what the humor is really telling about. By picturing the inferiorities of women, the disparaging element should be credited for the laughter. Some psychological observations confirm that items of disparaging humor tend to get the highest ratings for funniness (Graesser et al. 1989: Schwars, 2010). Therefore, if there is no negative stereotypical image attaches to this humor, the humor may arouse less or even no laughter. The disparagement appears because the humor panders the stereotype of woman as having no brain power. This humor agrees with the old traditional myth that woman is biologically destined to be less intelligent than man. Secondly, the woman is portrayed as having less economic power by describing her as someone with no business or no work. It is obvious that the humor successfully portrays the dominance and superiority of man by putting woman as the object of laughter.

\section{Twisting Figurative Language}

Figurative language uses figures of speech to represent something in a connotative way. Apart from its wide use in media and communication, figurative language is also exploited to be a prominent tool for humor. This study also finds that humor twists the meaning from connotative meaning to denotative meaning:

(4) Q: What do you do with a man who thinks he's God's gift?

\section{A: Exchange him. (Datum 5)}

The expression "God's gift" refers to an expression that is used in a different way from the normal meaning. The metaphor "God's gift" is a vehicle to transfer an image of an extremely admirable, valued, or talented person; and when the expression is used, it can directly generate laughter because it is usually used in the ironical situation to describe people who think that they are perfectly attractive and admirable (Longman Electronic Dictionary, 2005). In other words, the expression "God's gift" is used to describe a person who brags or thinks that he/she is perfect, special, talented, etc. Notice also that the noun gift serves as the base for the adjective gifted.

However, it triggers laughter even more when the expression is twisted and treated in a denotative way. The expression God's gift describing man in the set-up of the humor connotatively contains [+ANIMATE, +HUMAN, + MALE]. And yet, the punch line creates different set of semantic 
components: [-ANIMATE, -HUMAN]. Therefore if $\mathrm{X}$ is the connotative meaning, $\mathrm{Ml}$ the expected meaning, and $\mathrm{M} 2$ the other alternative meaning, the formulation of the logical mechanism of this humor can be also written as:

X God's gift

$\mathrm{Ml}$ an extremely admirable, valued, or talented person

M2 an object which can be exchanged

From the semantic analysis above, the first and second meanings are totally different from each other. In the set-up the meaning of God's gift is closer to $\mathrm{Ml}$ although it can be interpreted as M2.

$$
\mathrm{X}=\mathrm{M} 1 ; \mathrm{X}=\mathrm{M} 2 \mathrm{M} 2^{\wedge} \mathrm{M} 1 \mathrm{X}=\mathrm{Ml}^{3}
$$

The punch line succeeds in twisting the figurative language into the M2 via the word "exchange". Here the humor successfully twists the connotative meaning into denotative meaning:

$$
\mathrm{X}=\mathrm{M} 2 \mathrm{X}^{\wedge} \mathrm{Ml}^{4}
$$

Making these two very different planes-man and gift-compatible, the humor succeeds in feeding some people the need for laughter. This humor is only intended to make fun of man who is stereotyped with some psychological trait, like bragging. Besides giving the stereotype "boastful" to man, this humor also considers man insignificant; he can be exchanged as an object.

\section{Absurd Neologism and Interpretation}

In morphology, this kind of humor undergoes what is called word formation, or the creation of a new word. One type of word formation is called neologism, which indicates a word or phrase newly invented or newly introduced into a language. Generally, neologism is a word, term, or phrase which has been recently created to apply to new concepts or synthesize preexisting concepts, to make older terminology sound more contemporary. In most neologism, there is a logical relationship between the old term and the new concept, so that they are acceptable in the community. However, these selected humors use straightforward juxtaposition by interpreting the old term with a new, absurd, unacceptable concept. 
(5) Bar-be-que (bar*bi*q) n. You bought the groceries, washed the lettuce, chopped the tomatoes, diced the onions, marinated the meat and cleaned everything up, but, he "made the dinner." (Datum 9)

The form of this humor is constructed like an entry in a dictionary, complete with its pronunciation and part of speech. However, "barbeque" in any English dictionary is obviously not defined that way. Thus, the definition of this word which is far from the accepted truth creates laughter. This humor shows another representation of man and woman in the division of house labor. The woman does all the preparation to make a barbeque. And yet, the man, although having his hands free, is boastful about making the dinner.

However, besides absurd neologism, some humors also exploit the meaning of an expression by giving it an absurd interpretation. There are also humors that involve false translation. It should be born in mind that this is not a real translation which renders messages from one language to another. Yet, the humor below is deliberately "translating" the expression incorrectly to create humorous outcome.

(6) Woman's translation: Do you love me? = I'm going to ask for something expensive. (Datum 15)

The humor portrayal, however, mirrors the outside social world in which the male dominance in economic power, specifically in the working field, remains the norm (Wilis, 2002). Accordingly, women are ridiculed for their dependence on their husband economically. Once again, humors of this type work because they create an incongruent script opposition and succeed in disparaging others.

\section{False Analogy}

Analogy is a comparison between two things that are similar in some way. Encarta (2007) defines it as a form of logical inference, reasoning that if two things are taken to be alike in one way, they are alike in other ways. However, when two concepts, objects, or events are compared based on weak similarities and applied across the board, the comparison is called false analogy. According to Daniel Kies (Online, 2012) false analogy is a comparison which is based on just a few similarities, while ignoring heaps of differences. Interestingly, the more illogical the things compared, the more incongruent the script becomes, and the funnier it is.

(7) What do men and beer bottles have in common?

They are both empty from the neck up! (Datum 20) 
Stereotyping in Gender Cyber Humors

Given this riddle, both the humor teller and the reader are involved in a nonbona-fide situation. The set-up (see Table 4.9.) "What do men and beer bottles have in common?", as Grice (1975) puts it, is a non-bona-fide communication (violating maxims) because it compares men [+ANIMATE, +HUMAN] with bottles [-ANIMATE, -HUMAN]. Given a non-bona-fide set-up, the reader is driven to find a non-bona-fide punch line too.

However, inside this riddle, the incongruous comparison between bottles and men involves false analogy. Because both men and beer bottles have necks, they are assumed to share another characteristic, that is, "empty". To make it more clear, if T1 (thing 1) refers to the object being compared, T2 refers to men, $\mathrm{X}$ is the similar characteristic between them, and $\mathrm{Y}$ is $\mathrm{Tl}$ 's characteristic, then the logical mechanism of the humor can also be written as:

\section{T1 bottles $\mathrm{T} 2$ men}

$\mathrm{X}$ a shared similar characteristic (neck) Y; Tl's characteristic (empty). The set-up:

$$
\begin{aligned}
& \mathrm{T} 1 \wedge \mathrm{T} 2 \mathrm{Tl}=\mathrm{X}, \mathrm{T} 2=\sim \mathrm{X} \mathrm{T} 1=\mathrm{Y}^{5} \text { The punch line: } \\
& \mathrm{Tl}=\mathrm{Y}=\mathrm{T} 2^{6}
\end{aligned}
$$

Unlike the lexical ambiguity in humor (1), in which the preposition for contains two different meanings $\left(X=M 2 \rightarrow X^{\wedge} M 1\right)^{7}$, false analogy works when the two things overlap each other partly by ill-judging them $(\mathrm{Tl}=\mathrm{Y}=$ T2). In humor (7), although both bottles and men are given the predicate "empty", this adjective assigns different meanings to each subject. Outside the humor, "empty" is an adjective describing the condition of a noun as having nothing inside. When it is associated with "bottle" [+THING], then it means denotatively: from the neck up, the bottle is empty. However, if it modifies "man" [+HUMAN], then it creates a figurative effect that man (any man) is brainless.

The incongruity, again, makes the reader burst into laughter. And yet, the incongruity alone does not constitute the humorous effect. The humor demonstrates that it also depends on the social implications given to the butt of the humor. Although representing men as stupid contradicted the traits of masculinity some decades ago, now they metamorphose to be the butt of a bacillus of laughter too. It indicates that stereotyping is not absolute; it changes through time. 


\section{Fallacious Reasoning}

In any writing textbook, when writing, one needs to build a thesis statement, supported by strong arguments based on some logical explanation. According to Daniel Kies (Online 2012), when writers employ logic in composition, the emphasis seems to be on determining whether the reasoning behind an argument is valid or invalid, and then using those determinations to support or reject a thesis. But, sometimes, people slip and create fallacy in reasoning. An example of false reasoning is when a person recieves bad luck three times on three successive Wednesdays and concludes that Wednesday is his unlucky day (Soedjatmiko, 1988). If the premises are vague, incongruous or totally illogical, then they may result in absurdity; some, with stereotyping and insult, may create laughter. Humorists can construct a humorous/false proposition to attract the readers without the need to provide good evidence or premises at all. The logic between premises and the inference may create amusement if it is exploited and results in illogicality like what is found in this humor:

A bum asks a man for $\$ 2$. The man asked, "Will you buy booze?" The bum said, "No." The man asked, "Will you gamble it away?"The bum said, "No." Then the man asked, "Will you come home with me so my wife can see what happens to a man who doesn't drink or gamble?" (Datum 31)

At first, before arriving at the punch line, the interpreter thought that the man asked the bum those questions because he didn't want to give his money to the bum who would buy booze and gamble it away. Although it turns out that the bum, whom the husband comes across, is a man who does not drink and gamble, the story violates the reader's expectation by his final conclusion that involves false logic. The humor converts the condition of a specific situation to make a general conclusion; if $\mathrm{X}$ is $\mathrm{Y}$, then $\mathrm{Y}$ is $\mathrm{X}$ :

If the bum is a man who does not drink and gamble, every man who does not drink or gamble is a bum.

In the punch line, the man generalized that a man (any man) who does not drink or gamble is (or looks like) a bum [MAN, GOOD FOR NOTHING]. From the absurd conclusion, this humor pokes fun at men's addiction to boozing and gambling. All in all, the humor teller deliberately chooses not to supply the humor with logical reasoning. The humor just needs to employ some negative stereotypes to create a humorous effect. 
Stereotyping in Gender Cyber Humors

\section{Word Repetition}

There are humors that exploit word repetition to make the expressions unique and attractive. The repetition of words in these humors gives more sonorous sound to highlight the contrast between man and woman; because without the substance of repetition in the humors, they will be an ordinary sentence instead of a creative tool for laughter. Through word repetition, the humor bellow indicates the superiority of man and the inferiority of woman.

(9) A successful man is one who makes more money than his wife can spend. A successful woman is one who can find such a man. (Datum 34)

Given this sentence, it is important to notice how the humor defines the word "successful". The first sentence defines a successful man as a man who makes more money than his wife can spend. However, the second sentence gives a heartbreaking definition about a successful woman because the concept of "successful" when attached to woman is wrongly exploited.

The word "successful", as defined by Encarta Dictionary 2007, means "having achieved or gained much, especially wealth, fame, or power". So, it can be semantically written as [+HUMAN, +/-MALE, + WEALTH, +FAME, +POWER]. From the semantic analysis, both man and woman can be successful. Nevertheless, the humor turns the definition of this adjective the other way around. From the humor, the phrases "successful man" and "successful woman" can be semantically analyzed:

Successful man [+HUMAN, +MALE, +MONEY]

Successful woman [+HUMAN, -MALE, +SUCCESSFUL MAN]

It is obvious that this sentence gives a wrong definition of being a successful woman. If this sentence is scrutinized, then, according to the humor, woman's being successful depends on man's success. Again, the woman's dependency in terms of economic power appears in this humor. The superiority and dominance of man over woman are the main factors that account for the humor.

\section{Insult Humor or Put-down Humor}

Having analyzed the humors above, it can be noticed that there are elements of incongruity and superiority in each of them. There is some wit in language play to insult a certain sexual group. Yet, the researchers find that 
there are some humors that are mainly, or mostly, constructed by sound insults. An insult is an expression, statement or behavior that is considered degrading. Insults, which happen just around any corner, are produced intentionally or accidentally. Intentional insults in gender humors are expressed due to underestimating intelligence or knowledge of the other.

Under this classification are gender humors that do not foreground the linguistic devices like the above humors. Unlike the previously discussed humors which use various ways of playful logic and smart language mechanisms as vehicles to poke funat men's or women's inferiorities and deficiencies, the humors classified in this section put down the other party openly for their stereotypical images.

(10) I date this girl for two years - and then the nagging starts: "I wanna know your name..." (Datum 37)

(11) Q: Why do men like smart women? A: Opposites attract. (Datum 50)

Compared with the previous humors, these humors contain less incongruity elements. Humor (10) makes use of the stereotype that a girl (no specific girl mentioned) is always nagging. Humor (11), with an economic and sarcastic reply, also belittles man's intelligence. Although there are few elements of language manipulation creating humorous effects, both humors have sound insults.

Looking back at the afore-mentioned theories, Schopenhauer and Kant (Monro, 1988) stand for the incongruity theory, while Hobbes and the others stick to the superiority theory. In light of the discussions on humors above, the exploitations of linguistic elements (listed in an increasing order of complexity in Table 1) do matter. Through this incongruity which is covered by various narrative styles, it can be seen how creative human minds are in producing and backtracking incongruity in humors.

To recapitulate, each gender humor has its own logic. Dissecting the humors by means of GTVH opens a way to see how logical mechanisms in gender humors operate; and exposing semantic features reveals how the reader's expectation is given a sudden surprise by an incongruent text. Despite all the incongruities that constitute gender humors, there is also one fundamental ingredient that triggers humors: the element of superiority. Without the stereotypical images showing the inferior and the superior, the humorous effect would work less. The element of superiority can be traced by 
scrutinizing the targets of the humors: man and woman-a binary opposition put in endless rivalry for the sake of verbal play.

\section{Stereotyping in the Selected Gender Humors}

In addition to uncovering the types of logical mechanism, the data analysis also yields gender stereotyping typical of gender humors. So, what are the sexist matters or the distorted images of the party being poked fun at? As listed in Table 3, the reader can take a close look at the distorted images of man and woman that count for the jocular effects. Notice that all stereotypes have negative meanings. Going from the top to the bottom, man and woman are equally insignificant (3\%: $3 \%$ ); woman is a lot more bothersome than man $(16 \%: 2 \%)$; man is much more stupid than woman $(18 \%: 4 \%)$; man is also more ugly than woman (6\%: $2 \%)$; and both man and woman are equally uneconomical and attracted to gender-bias attitudes (1\%: $1 \%)$.

Then there are stereotypical negative images pertaining only to man: immature (2\%), not understanding (4\%), stubborn $(2 \%)$, and addicted to drinking and gambling (2\%). Similarly, woman is also portrayed with typically female-negative stereotypes: being a homemaker (10\%), economically dependent (12\%), and jealous (4\%). Thus, as stocks for laughter, man and woman are assigned their respective disapproving traits: macho-negative stereotypes for man, and nagging-negative stereotypes for woman. While this negative stereotyping is necessary for creating a humor victim, the distorted images of both sexes are nevertheless in accord with findings on gender roles in earlier studies by Chavetz (1978) and Craig (1992).

Table 3:

Gender Stereotypes in Gender Humors

\begin{tabular}{|c|l|c|c|c|c|c|c|}
\hline \multirow{2}{*}{ No. } & \multirow{2}{*}{ Gender Stereotypes } & \multirow{2}{*}{$\sum$} & \multirow{2}{*}{$\%$} & \multicolumn{2}{|c|}{ Man } & \multicolumn{2}{c|}{ Woman } \\
\cline { 5 - 8 } & & & & $\sum$ & $\%$ & $\sum$ & $\%$ \\
\hline 1 & Insignificant & 6 & 12 & 3 & 6 & 3 & 6 \\
\hline 2 & Bothersome & 9 & 18 & 1 & 2 & 8 & 16 \\
\hline 3 & Stupid & 11 & 22 & 9 & 18 & 2 & 4 \\
\hline 4 & Ugly & 4 & 8 & 3 & 6 & 1 & 2 \\
\hline 5 & Uneconomic & 1 & 2 & 0.5 & 1 & 0.5 & 1 \\
\hline 6 & Gender Differences & 1 & 2 & 0.5 & 1 & 0.5 & 1 \\
\hline 7 & Immature & 1 & 2 & 1 & 2 & - & - \\
\hline 8 & Not Understanding & 2 & 4 & 2 & 4 & - & - \\
\hline 9 & Stubborn & 1 & 2 & 1 & 2 & - & - \\
\hline
\end{tabular}




\begin{tabular}{|c|l|c|c|c|c|c|c|}
\hline 10 & $\begin{array}{l}\text { Drinking and Gambling } \\
\text { Addict }\end{array}$ & 1 & 2 & 1 & 2 & - & - \\
\hline 11 & Homemaker & 5 & 10 & - & - & 5 & 10 \\
\hline 12 & Economically Dependent & 6 & 12 & - & - & 6 & 12 \\
\hline 13 & Jealous & 2 & 4 & - & - & 2 & 4 \\
\hline & & & & & & \\
\hline & Total & 50 & 100 & 22 & 44 & 28 & 56 \\
\hline
\end{tabular}

Some studies related to this issue have been conducted by anthropologists and psychologists. They came up with interesting findings that reflect the common standard of traditional humors. In her article "Gender and Humor: An Introduction”, Helga Kotthoffs (2006: 12) states that:
Anthropologists such as Gershon Legman (1968), who have compiled large international collections of humors, have found that the sexually explicit humor plays an important culture- transcending role and that a large share of these humors are at the expense of women (also Fine 1976). In the meantime, the women's movement has produced changes in the domain of standard jokes.

With this finding, women's deficiencies were once the dominating factors that were responsible for laughter. In other words, women became the object of male laughter. Moreover, Ken Willis (2002) in her Ph.D dissertation states that Blyth, a 1953 American humorist, considered women only fitted as men's object of laughter because of their subordination. Nevertheless, scrutinized diachronically, this study agrees with Khotthoff's statement (2006) that men's deficiencies, as displayed in Table 3, have also become common place. The shift from poking fun at women only to both men and women is a result of women's revolutionary movement in the West, including English-speaking countries.

Going back to the earlier study by Chavetz (1978), her findings about masculine and feminine traits can be put in binary opposition: masculine/feminine, athletic/weak, breadwinner/ domestic, sexually aggressive/sexually passive, unemotional/emotional, logical/intuitive, dominating/dependent, etc. Derrida (1978) argued that in most binary oppositions there is power relationship between the binary since one of the binary is usually more dominant than the other. It is apparent that central authority or superiority is attributed to the first, masculine terms in the 
Stereotyping in Gender Cyber Humors

binary oppositions, implying that the second, feminine terms belong to the inferior or weak party.

These traditional traits and images of men and women are now being compared with the portrayals of men and women within the selected humors to see whether or not the humors endorse the traditional role stereotypes. For this purpose, most contents of Table 3 are re-presented in Table 4 to compare between traditional and non-traditional stereotypes pertaining to both men and women.

Recall that in analyzing gender humors the targets are portrayed using negative stereotypes. Referring to Table 4, there are 3 traditional stereotypes: homemaker, economically dependent, and bothersome-all being typical characteristics of women. While the term "homemaker" has been used lately to replace the older derogatory term "housewife", it fails to elevate the social status of women. Being a homemaker was originally intended to mean that a wife is a powerful figure in managing domestic affairs.

Table 4:

Stereotypes of Man and Woman in Gender Humors

\begin{tabular}{|c|c|c|c|c|c|}
\hline \multirow{2}{*}{ No. } & \multirow{2}{*}{ Stereotype } & \multicolumn{4}{|c|}{ Humor Target } \\
\hline & & \multicolumn{2}{|c|}{ Man } & \multicolumn{2}{|c|}{ Woman } \\
\hline \multicolumn{2}{|r|}{ Traditional } & $\sum$ & $\%$ & $\sum$ & $\sum$ \\
\hline 1 & Homemaker & - & - & 5 & 10 \\
\hline 2 & Economically dependent & - & - & 6 & 12 \\
\hline 3 & Bothersome & 1 & 2 & 8 & 16 \\
\hline \multicolumn{2}{|r|}{ Non-traditional } & $\sum$ & $\%$ & $\sum$ & $\sum$ \\
\hline 1 & Insignificant & 3 & 6 & 3 & 6 \\
\hline 2 & Stupid & 9 & 18 & 2 & 4 \\
\hline 3 & Ugly & 3 & 6 & 1 & 2 \\
\hline
\end{tabular}

However, the modifier "home" in "homemaker" is still much too close in meaning to the modifier "house" in "housework". So, a wife is fully in charge of doing all housework, as ridiculed in the following humor.

(12) Men's translation:

WE SHARE THE HOUSEWORK. 
"I make the messes; she cleans them up."

Humor (12) obviously puts men in the dominant position, and women in subordination. While in this humor men are presented as uncaring, thoughtless, and egoistic, women are presented as weak and helpless. Both men and women are victims of the humor: the oppressors and the oppressed, with superiority assigned to men.

Further, since a homemaker has her power only within the confines of the homestead, outside this domain she becomes powerless. Therefore, as homemakers, wives are ridiculed by gender humors as being dependent economically on their husbands. The dominance issues with regard to economic power come to the fore, as in the following humor:

(13) A couple was having a discussion about family finances. Finally the husband exploded, "If it weren't for my money, the house wouldn't be here!" The wife replied, "My dear, if it weren't for your money I wouldn't be here." (Datum 36)

The wife in humor (13) reminds us of "a successful woman" as defined by humor (9); she is one who can find a very rich man. Women are targeted in gender humors because of the stereotypes suggesting that they are materialistic, shopaholic, having no business or penniless. Ironically, this kind of dependency depicted in the humors comes not only from men's mindset, but also from women's mindset. The man thinks that the woman is only capable of spending his money. Similarly, the woman thinks, and even instructs other women, to be dependent financially on the man (datum 3). It is not unusual that women are portrayed as consumerists (MoranjakBamburac, 2006; Londo, 2006). Londo (2006) argued that magazines and other media give emphasis on women beauty, burdening them with the achievement of ideal beauty at any cost. In the humor, the power relationship portrayed is established through the binary opposites: moneyprovider vs. money-spender. The binary opposition of independency/dependency in terms of economic power suggests that traditional stereotypes of men and women nowadays are still firmly established.

Thus, the three traditional stereotypes presenting negative images of women (listed in Table 4) come in one package. As a "homemaker" (10\%), the woman is "economically dependent" $(12 \%)$ on the man. If the man fails to provide what she needs, she becomes "bothersome" (16\%), nagging. 
Notice, however, than men are also bothersome (2\%), although much less than women.

Whereas the traditional stereotypes take only women as stocks of laughter, the non-traditional stereotypes mainly work the opposite way. Men and women are equally "insignificant" $(6 \%)$, cheap creatures. The rise of this gender equality goes along with the ascending spirit of feminism. As noted in Tong (1998), Simone de Beauvoir (1960) introduced the opposing terms "the One" and "the Other" in her book The Second Sex. In her analysis, "the One" refers to man, while "the Other" refers to woman; and "the One" is more dominant than "the Other". The otherness used to be assigned to woman because she was considered having no power and hence insignificant. However, today a woman is no longer the second sex. There are extreme humors that portray how both man and woman are insignificant: a man prefers his dog to his wife, a man prefers a set of golf clubs to his wife, a man gets bored with a woman and wants to shoot her, a woman thinks that all men should be put on the moon, and a woman thinks about changing her man like changing gifts.

Interestingly, when it comes to "ignorance", men are better targets. The degrading adjective "stupid" is assigned to men (18\%) a lot more frequently than to women (4\%).

\section{What do you call a man with an I.Q. of 50 ?} Gifted! (Datum 47)

The irony is at work here, which requires a deeper psychological analysis. Men are assumed to be rational, practical, aggressive, while women are assumed to be expressive, nurturing, and emotional (Beynon 2002). Chavetz (1978) also suggests that men are "logical" creatures, while women are "intuitive" creatures. These images again show how superior men are in terms of intelligence and power of reasoning. However, some feminists perceive this stereotype inside out. They say that men are actually more primitive creatures than women because men cannot escape from their primitive impulses, i.e. sex, hunger and pleasure (Wilis, 2008). However, humors making fun of men's stupidity are non-stereotypical. Some decades ago, it was absurd to ridicule men's stupidity, but now it becomes commonplace. It stands to reason to say that traditional stereotypes, just like cultural values in any society, are in flux.

Finally, the negative attribute "ugly" is attached to both men and women. Beauty has been shaped in the society through fairy tales. Good 
women are beautiful, and bad women are old or ugly. Similarly, good men are also portrayed as handsome princes, and bad men as ugly ogres. The fairy tales reflect that physical appearance is considered valuable in the society. However, with the insulting adjective "ugly", men (6\%) get a bigger share than women (2\%), as illustrated by the following example:

Q: Where is the best place in a book store to find a man who is handsome, a good lover and a stimulating partner?

A: In the pages of a romance novel. (Datum 46)

The punchline in humor (15) "In the pages of a romance novel" tells the reader that a handsome, romantic, and stimulating man does not exist in reality; he exists only in fiction. In the real world there are only men presenting themselves as ugly and unexciting bores.

In sum, gender humors are funny through negative stereotyping. Traditionally, only women were taken as the targets, for the female gender was perceived as weak, dependent, and bothersome. However, as the feminist movement in the western world has succeeded in gaining momentum, social changes have occurred accordingly. Both sexes are now perceived more or less equally, either in a positive or negative way. In effect, both men and women are taken to be victims of gender humors. Both sexes can be of little value, and men can be more ignorant and ugly than women.

\section{CONCLUSION}

Gender humors have a unique way of triggering laughter, not only by twisting the logical structure of the humorous text but also by depreciating either the male or female party. The overarching stereotypes in the surface of the humors have also been explored in this research. The literature mentions that some decades ago, the common standard of the humors laughed at women's stereotyped deficiencies. However, owing to women movements in English-speaking countries, and in the western world in general, the roles and representations of women in the society keep changing; this phenomenon affects the shift in the common standard of the humors. From the findings and discussions in the previous section, gender humors poke fun at men's deficiencies too.

As for the logical mechanism of the humors, it is much like the syntactic structure of a sentence. In generative grammar (Chomsky, 1957, 
1965), it is formally represented by the re-write rule [S $\rightarrow$ NP VP], which reads "every sentence (in English) consists of an NP subject and a VP predicate". Likewise, several incongruities of the humors, which the reader has passed through, are represented by formal notations following the model in Attardo's (2001) GTVH theory. This mathematical rigor is a serious attempt to explicate the incongruities characterizing gender humors. Thus, as seen from the perspective of discourse analysis (see Thornbury, 2005), gender humors are texts which are coherent in an eccentric way.

Going down to the deeper level, there are two main ships in the discussion of the philosophy of humor analyzed in this study. The crew members of the first ship are big thinkers, like Hobbes, Gruner, and Jakobson (Monro, 1988), who propose that superiority is an inseparable element of humor. Furthermore, they suggest that people are laughing because of the superior feeling towards the inferiority of others. However, on the other side of the sea of humor is the ship with great philosophers like Kant and Schopenhauer, (Monro, 1988), who consider incongruity and humor are like soul and matter. Nevertheless, after dissecting all the selected gender humors, the researchers come in the middle of those two ships. We come with a perspective that incongruity and superiority elements actually work together as the ingredients constituting gender humors.

On the basis of the research findings, the researchers suggest that the readers attempt to avoid sexist matters in humors and be more critical in using humors when communicating with others to avoid harm. For future researchers, a close look at gender humors in different languages, e.g. Indonesian, Javanese, Sundanese, and other local languages, can be a challenging research project because, however slight, the way other cultures see gender is different from the way English-based speaking countries see it. Besides, limited to uncovering major elements of gender humors and gender stereotypes, this study has not gone further to find out the effect of gender humors on the society. Further investigation on this matter will probably lead to a novel contribution to the literature of gender and humor.

\section{REFERENCES}

Aha!jokes, Retrieved September, 2015 from http://www.aha!jokes.com (2007). Encarta Electronic Dictionary. 1993-2006 Microsoft Corporation.

(2005). Longman Dictionary of Contemporary English. London: Longman. 
46 Celt, Volume 16, Number 1, July 2016, pp. $22-48$

Attardo, S. (2001). Humorous Texts: A Semantic and Pragmatic Analysis. Berlin: Mouten de Gruyter.

Attardo, S. \& Raskin, V. (1991). Script Theory revisited: Joke Similarity and Joke Representation Model. Humor 4-3 (4), 293-347.

Azis, A.L. (2008). Ucup Kelik's "Plesetan": A Study of Twisting Linguistic Ambiguity in Oral Verbal Humor. Unpublished undergraduate thesis. Malang: Faculty of Letters of State Unversity of Malang.

Bennett, P.B. \& Lengacher, C. (2006). Humor and Laughter May Influence Health. Retrieved August, 2015 from http://www.ncbi.nlm.nih.gov/pmc/ articles/PMC1375238/

Chavetz, J. (1978). Masculine, Feminine or Human?: An Overview of the Sociology of the Gender Roles, 2nd ed.. Itasca, IL: F.E. Peacock Publishers.

Chomsky, N. (1957). Syntactic Structures. The Hague: Mouton.

Chomsky, N. (1965). Aspects of the Theory of Syntax. Cambridge, Massachusetts: The MIT Press.

Derrida, J. (1978). Writing and Difference. Trans. Bass, Chicago: University of Chicago Press.

Grice, H.P. (1975). Logic and Conversation. In Cole, P. \& Morgan, J. (eds.) Syntax and S, 3. New York: Academic Press, 41-58.

Gruner, C.R. (1976). Understanding Laughter: The Workings of Wit and Humor. Chicago: Nelson-Hall. (Online),

Kadarisman, A.E. (2002). Trends and Issues in Linguistics: Teaching Materials. Malang: Unpublished.

Kies, D. (2012). Using Logic in Composition. Retrieved June 2015 from http://papyr.com/hypertextbooks/comp1/logic.htm

Kotthoff, H. (2006). Gender and Humor: The State of the Art. Journal of Pragmatics. 38 (1), 4-25.

Laineste, L. (2008). Politics of Joking: Ethnic Jokes and Their Targets in stonia (1890s- 2007). Folklore: Electronic Journal of Folklore, 40, 117-146

Latief, M.A. (1999). Penelitian Kuantitatif dan Kualitatif. Forum Penelitian Kependidikan, 11 (2), 103-116. 
Stereotyping in Gender Cyber Humors

Lim, T.C. (2004). Advanced English Idioms for Effective Communication. Jakarta: Penerbit Erlangga.

Londo, I. (2006). Career, Beauty and Motherhood: Representation of Gender Role in Women Magazines in Albania. Stereotyping Representation of Women in Print Media in South East Europe. Moranjak-Bamburac, N., Jusic, T., \& Isanovic, A., Eds. Sarajevo: Mediacentar Sarajevo.

Monro, D.H. (1988). Theories of Humor. Writing and Reading Across the Curriculum, 3rd ed. Laurence Behrens and Leonard J. Rosen, eds. Glenview, IL: Scott, Foresman and Company.

Moranjak-Bamburac, N. (2006). The Unbearable Lightness of Stereotypes. Stereotyping Representation of Women in Print Media in South East Europe. Moranjak-Bamburac, N., Jusic, T., \& Isanovic, A., Eds. Sarajevo: Mediacentar Sarajevo.

Paramitasari, L. (2007). Twisting Linguistic Ambiguity in Written Verbal Humor in Reader's Digest. Unpublished Undergraduate Thesis. Malang: Faculty of Letters of State University of Malang.

Raskin, V. (1985). Semantic Mechanisms of Humor. Dordrecht: D. Reidel Publishing Company.

Schwarz, J. (2010). Linguistic Aspects of Verbal Humor in Stand-up Comedy. Dissertation. Saarbrücken: Universität des Saarlandes.

Soedjatmiko, W. (1988). Linguistic and Cultural Analysis on American Written Verbal Humor and its Pedagogical Implication. Unpublished Dissertation. Malang: Postgraduate Faculty of State University of Malang.

Spencer, S.J., Steele, C.M., \& Quinn, D.M. (1999). Stereotype Threat and Women's Math Performance. Journal of Experimental Social Psychology, 35, 4-28.

Thornbury, S. (2005). Beyond the Sentence: Introducing Discourse Analysis. Oxford: Macmillan.

Tong, R.P. (1998). Feminist Thought: Pengantar Paling Komprehensif kepada Arus Utama Pemikiran Feminis. Yogyakarta: Jalasutra.

Wilis, T.T. (2008). Disney's Mulan: Upholding misogyny. Unpublished Undergraduate Thesis. Malang: Faculty of Letters of State Unversity of Malang.

Willis, K. (2002). Making Sense of Humour: Some Pragmatic and Political Aspects. Retrieved February, 2008 from http://www.pragmaticshumour.net/making senseofhumour.htm 
48 Celt, Volume 16, Number 1, July 2016, pp. 22-48

\section{Notes:}

The researchers are aware of the fact that not all readers are familiar with mathematical notations representing the logical structures of several gender humors. Therefore, all the mathematical notations in the third section of the article, "Findings and Discussion", are cited here in their order of presentation, provided with their verbal reading.

${ }^{1} \mathrm{X}=\mathrm{Ml}, \mathrm{X}=\mathrm{M} 2 \mathrm{Ml} \wedge \mathrm{M} 2$

$\mathrm{X}$ is $\mathrm{M} 1 . \mathrm{X}$ is $\mathrm{M} 2 . \mathrm{M} 1$ is not synonymous with $\mathrm{M} 2$

${ }^{2} \mathrm{X}=\mathrm{M} 2-\gg \mathrm{X}^{\wedge} \mathrm{M} 1$

$\mathrm{X}$ is $\mathrm{M} 2 . \mathrm{X}$ is not $\mathrm{M} 1$ in the punch line.

${ }^{3} \mathrm{X}=\mathrm{M} 1, \mathrm{X}=\mathrm{M} 2 \mathrm{M} 1 \wedge \mathrm{M} 2$

$\mathrm{X}$ is $\mathrm{M} 1, \mathrm{X}$ is $\mathrm{M} 2 . \mathrm{M} 1$ is not synonymous with $\mathrm{M} 2$.

${ }^{4} \mathrm{X}=\mathrm{M} 2$-» $\mathrm{X}^{\wedge} \mathrm{Ml}$

$\mathrm{X}$ is $\mathrm{M} 2 . \mathrm{X}$ is not $\mathrm{M} 1$ in the punch line.

${ }^{5} \mathrm{~T} 1 \wedge \mathrm{T} 2 \mathrm{Tl}=\mathrm{X}, \mathrm{T} 2=\sim \mathrm{X} \mathrm{T} 1=\mathrm{Y} \mathrm{T} 2=\mathrm{Y}$

T1 is not T2. T1 has X. T2 does not have X. T1 has Y. T2 has Y. ${ }^{6} \mathrm{Tl}=\mathrm{Y}=\mathrm{T} 2$

$\mathrm{T} 1$ and $\mathrm{T} 2$ have $\mathrm{Y} . \mathrm{T} 1$ equals $\mathrm{T} 2$.

${ }^{7} \mathrm{X}=\mathrm{M} 2-\gg \mathrm{X}^{\wedge} \mathrm{Ml}$

$\mathrm{X}$ is $\mathrm{M} 2 . \mathrm{X}$ is not $\mathrm{M} 1$ in the punch line. 